\title{
Microbial and Biochemical Changes Occurring During Production of Traditional Rwandese Banana Beer "Urwagwa”
}

\author{
Parawira Wilson*, Tusiime David and Binomugisha Sam \\ Department of Applied Biology, Kigali Institute of Science and Technology (KIST), Avenue de I'Armee, B.P. 3900 Kigali, Rwanda
}

\begin{abstract}
Banana beer, urwagwa, is one of the oldest and major alcoholic beverages traditionally processed in Rwanda produced mainly at homes as a family business. The banana beer is manufactured from fermentation of bananas which is an important crop economically and culturally in Rwanda. The processing methods of urwagwa have not yet improved and traditional methods are still in use. Microbial and biochemical changes that occur during production of traditional Rwandese banana beer were investigated in this study. Understanding the microbiological and physicochemical changes is essential in attempts to upgrade the traditional processing commonly used to commercial scale. Banana ripening, extraction of juice from banana and fermentation to produce beer was done using modified traditional methods. During fermentation to produce banana beer, total aerobic mesophilic bacteria, lactic acid bacteria, yeast and molds increased with fermentation time. The presence of high numbers of yeast and lactic acid bacteria $\left(3.12 \times 10^{9}\right.$ and $4.12 \times 10^{13} \mathrm{cfu} / \mathrm{ml}$, respectively) shows that the natural fermentation was a mixed alcohol and lactic acid fermentation. Titratable acidity increased from $0.18 \%$ lactic acid to $0.9 \%$ lactic acid, pH decreased from 4.78 to 4.0 , while alcohol concentration increased to $7 \% \mathrm{v} / \mathrm{v}$ after $72 \mathrm{~h}$ fermentation time. These results give an insight into the microbial and biochemical changes during traditional fermentation processes which is important in attempts to upgrade it to pilot and commercial scale. The study could serve as a starting point for a scientific understanding of the microbiological and physico-chemical processes in urwagwa production with the aim of improving the efficiency of the production.
\end{abstract}

Keywords: Banana beer; Microbial changes; Traditional fermentation; Biochemical changes

\section{Introduction}

The use of fermentation techniques is one of the oldest and most economical methods of producing and preserving foods [1-3]. Fermentation has many advantages such as inhibition of growth of spoilage and pathogenic microorganisms by producing organic acids and other compounds, improving organoleptic properties by producing different flavor compounds and often improving the nutritional value of the original foods [1,4-6].

Fermented beverages constitute a major part of the diet of traditional African rural and peri-urban homes, including Rwanda. Home-brewed banana beer or urwagwa is used to signify hospitality, to affirm bonds of social cohesion, and consumed in various social functions such as birth, weddings, and traditional festivals [7]. Brewing banana beer and cereal based beers for sale has increased economic importance for households $[8,9]$. Production and sale of banana beer provides additional family income, and may contribute significantly to the level of monetary transactions in rural and urban areas. The banana's year round harvest assures a continuous source of food and income.

Banana is the second largest produced fruit after citrus, contributing about $16 \%$ of the world's total fruit production [10,11]. Rwanda is one of the major producers of bananas in the East African Great Lakes Region. Banana cultivation occupies $23 \%$ of the country's arable land and contributes more than $50 \%$ of annual crop production in terms of fresh weight [12]. Banana is both a food and cash crop for most producers and therefore it is a key component of Rwanda's food security. Most banana production is on small family plots. A large number of clones are grown, including the local East African highland cooking and beer cultivars (AAA-EAHB) and introduced beer (AB, $\mathrm{ABB})$ and desert (AAA, AB) types. For the last 15 years, beer cultivars have dominated banana production (increasing from $67 \%$ to $71 \%$ at the expense of dessert types) (Food Security Research Project, 2000, unpublished). The proportions of different banana types within each region and at each site are influenced by market opportunities, dietary, preference, food security and the relative performance of the cultivars across a range of criteria [13]. The beer bananas are the predominant cultivars because they are favored by local farmers due to their higher market value, agriculturally better suitability and resistance to pests and diseases compared to cooking bananas [14]. Cooking bananas are widely viewed as poorly adapted to withstand stresses such as untimely rainfall, drought, declining soil fertility, intensive cropping systems (e.g., intercropping) brought on by land pressure and reduced management levels. Beer bananas having high astringency are not consumed by cooking but used for making beer.

Traditional banana beer is one of the oldest and major alcoholic beverage produced in most East African countries and is given different names in the different countries, for example it is called Urwagwa in Rwanda, Tonto in Uganda [15], Mbege in Tanzania [16], Urwaga in Kenya [3] isongo in Burundi [17]. It is mostly consumed on three quarters of Rwandan territory, where banana growing is a major agricultural activity. Urwagwa is mostly consumed in Kigali, Cyangugu, Kibuye, Kibungo and Gisenyi districts. Banana beer (commonly called

${ }^{*}$ Corresponding author: Wilson Parawira, Department of Applied Biology, Kigali Institute of Science and Technology (KIST), Avenue de l' Armee, B.P. 3900 Kigali, Rwanda, E-mail: parawiradr@yahoo.co.uk

Received November 25, 2011; Accepted April 24, 2012; Published April 26, 2012

Citation: Wilson P, David T, Sam B (2012) Microbial and Biochemical Changes Occurring During Production of Traditional Rwandese Banana Beer "Urwagwa", Ferment Technol 1:104. doi:10.4172/2167-7972.1000104

Copyright: (C) 2012 Wilson $\mathrm{P}$, et al. This is an open-access article distributed unde the terms of the Creative Commons Attribution License, which permits unrestricted use, distribution, and reproduction in any medium, provided the original author and source are credited. 
urwagwa) is produced from banana juice extracted from a variety of local bananas and blended with sorghum flour. The common local banana varieties used in making urwagwa are the harsh tasting Igikashi and the milder tasting Kamara [18]. Banana beer is made in different districts in Rwanda but is given different names like Urwedensiya, Rwabitoki, Urwarimu and Birenge. There are many variations in how the beer is made. For instance, urwagwa banana beer in Rwanda is made from bananas juice and sorghum or millet flour. In Rwanda, Burundi, Uganda, and Democratic Republic of Congo, beer is made from the blended juice of "beer" bananas and other banana varieties. Sometimes the juice is diluted with water (1:3 ratio or higher) to make a weaker beer which is preferred by other people while others prefer a strong beer made from undiluted juice. The banana beer from undiluted juice is regarded as very special and has a higher price than that from diluted banana juice. Some people prefer to drink the strained beer soon after one day fermentation while others prefer the product which has been fermented for more days.

To carry out any meaningful research on traditional beverages, the fundamental procedures used traditionally should be understood [19]. The preparation of banana beer is still basically a family art that is passed on from generation to generation orally. It involves ripening of bananas, juice extraction, and blending with ground sorghum and spontaneous fermentation to an orange, alcoholic beverage. The beer is consumed in an actively fermenting state and therefore has a quite short shelf-life. Banana beer is sweet and slightly hazy with a shelf life of several days under correct storage conditions. The beer is consumed unrefined, including unfermented substrates and microorganisms. The average alcoholic content of banana beer ranges from 6 to $11 \% \mathrm{v} / \mathrm{v}$ and depends on the production procedure, species of banana used, and the dilution ratio and, in many cases, the weather, since there is no proper mechanism to control the fermentation temperature [15]. It is liable to substantial changes in composition brought about by the actively metabolizing yeasts and lactic acid bacteria and other microorganisms which can be present. The microorganisms continue to grow even after acceptable levels of alcohol and lactic acid have been achieved. At this stage the presence of the microorganisms is no longer desirable. The short shelf life of banana beer and year round domestic demand is met by brewing at regular intervals. The short-life of most African fermented beverages is one of the major deterrents to their large-scale production and development as commercial products [20].

Urwagwa manufacturing is artisanal and characterized by absence of instrumental and analytical control like in most traditional alcoholic beverages. The fermentation of urwagwa is conducted using traditional materials, umuvure (woodened tanks), Ikibindi (clay pot), Ikidomoro (plastic tank). Urwina is a place where the bananas are kept for ripening.

The knowledge on banana beer production in Rwanda has not been scientifically documented and is in danger of being lost as technologies evolve and families move away from traditional food preservation practices. The manufacture of this beer is generally done under poor hygienic conditions which result in product with short shelf-life and variable quality and low alcohol content. The quality of the banana beer varies from one manufacturer to another and one brew to another. As a result, the urban consumers consider it a backward or poor people's drink. In Rwanda, no scientific studies of banana beer have been done on the microbiological and biochemical changes which occur during the production of the product. This study was, therefore, aimed at determining the microbiological and biochemical changes which occur during traditional banana beer production in Rwanda.

\section{Materials and Methods}

\section{Preparation of banana beer}

The preparation of urwagwa was done using "beer" bananas collected from rural areas in Rwanda. The ripening of the bananas, juice extraction and fermentation was done traditionally as practiced by the rural people of Rwanda.

Banana ripening: Unripe banana was harvested and carried to the home to be ripened. The different types of banana used were Kamara and Igikashi. All these types of banana were covered with grass and green banana leaves in order to ensure warm temperature condition which contributes a great role in ripening. The bananas were checked on the sixth day to assess their state of ripening where a yellow color and ease of peeling indicated the degree of ripeness. The state of ripening is tested by peeling the bananas by hand. On the seventh day the extraction of juice and its fermentation was commenced.

Juice extraction: The ripened bananas were peeled by hand and placed in a large wooden mortar, umuvure, and mixed with a special type of spear-grass (Imperata cylindirica) to assist in juice extraction. The grass was initially cut to lengths of about $30 \mathrm{~cm}$. The preferred grasses may differ from one region to another. The bananas mixed with the grass were worked or squeezed by hand to extract the juice until all the pulp was exhausted of juice. The juice was then strained with a sieve and the juice was collected into another wooden mortar or umuvure.

Fermentation: The collected juice was transferred into a 100-liter plastic tank (Ikidomoro) and diluted two times. Roasted red sorghum, which was coarsely crushed and ground, was added to the filtered juice to improve the color and flavor of the final product. The juice/sorghum mixture was left to ferment spontaneously at room temperature for 72 hours in the plastic tank. The product became sweet-sour with time. The brewing was done in duplicate plastic containers. The process of ripening bananas, juice extraction and fermentation of the final product took about 9 to 10 days.

Sampling: During fermentation a $50 \mathrm{ml}$ sample from each plastic container was collected after every 12 hours for 72 hours. The $\mathrm{pH}$ of each sample was measured immediately using a Mettler Delta 320 $\mathrm{pH}$ meter. Subsamples were collected for immediate microbiological analysis. The remaining part of the sample was centrifuged for 10 minutes at $6000 \mathrm{~g}$ and a sample of the supernatant was immediately analysed for titratable acidity.

\section{Microbiological Analyses}

Subsamples collected for microbiological analysis were diluted using peptone water and spread in triplicate on different media. Total aerobic mesophilic bacteria counts were made on plate count agar (DIFCO) after incubation at $37^{\circ} \mathrm{C}$ for 24 hours. Lactic acid bacterial counts were made on Man, Rogosa and Sharpe (MRS) agar (Oxoid) after incubation at $37^{\circ} \mathrm{C}$ for 48 hours. Yeast and molds counts were made on Rose Bengal Chloramphenical agar (SIGMA) after incubation at $30^{\circ} \mathrm{C}$ for 48 hours.

\section{Biochemical Analyses}

All assays were done in triplicate. Titratable acidity was measured immediately. The supernatant $(5 \mathrm{ml})$ collected during fermentation was transferred into a conical flask and diluted twice with distilled water. The solution was titrated against $0.1 \mathrm{M} \mathrm{NaOH}$ using phenolphthalein as the indicator [1]. The amount of acid produced was calculated as percent lactic acid according to the formula: 
\%lactic acid $=\underline{\mathrm{ml} \text { of } 0.1 \mathrm{M} \mathrm{NaOH}} \mathrm{X}$ normality of $\mathrm{NaOH} X$ mol weight of acid

\section{$\mathrm{ml}$ of sample X 10}

Sugar content was determined as ${ }^{\circ}$ Brix using a refractometer, (Bs eclipse, Bellingham Stanley 45-02 company UK). One degree Brix is equivalent to 1 gram of sucrose in 100 grams of solution and represents the strength of the solution as percentage by weight $(\% \mathrm{w} / \mathrm{w})($ strictly speaking by mass). The banana juice contained dissolved solids other than pure sucrose, therefore the ${ }^{\circ}$ Brix was only an approximate of the dissolved solid content as an indicative of the sugar content $[21,22]$. Alcohol content was measured by density measurement using hydrometer (Jeffy Welty, USA).

\section{Results and Discussion}

Results of the microbial analyses done during the fermentation of banana juice to urwagwa are shown in Table 1. There was an increase in numbers of total aerobic mesophilic bacteria, lactic acid bacteria and yeast and molds during the fermentation process.

Lactic acid bacteria, yeast and molds and aerobic mesophilic bacteria were found growing together during the 72 hours fermentation period, contributing to the characteristics of the final product, banana beer, probably by producing organic acids, ethanol, carbon dioxide and other volatile flavor compounds. According to Holzapfel [23], African beers are typical examples of lactic acid fermentation followed by alcoholic fermentation in which initially lactic acid bacteria and later yeasts play a predominant role. A symbiotic relationship could explain the presence of both yeasts and lactic acid bacteria in the banana beer, with lactic acid bacteria creating an acid environment favorable to the proliferation of yeasts. The yeasts produce vitamin and increase other nutritional factors such as amino acids for the growth of lactic acid bacteria [24]. The coexistence and free proliferation of lactic acid bacteria and yeasts, as was observed in this study, is a common occurrence in food and beverage fermentations [25]. Lyumugabe et al. [10] have recently reported the prevalence of total aerobic mesophilic bacteria, yeast and lactic acid bacteria from their study on microbiological and physicochemical analysis of Ikigage, a traditional malted sorghum beverage in Rwanda. Banana beer is a naturally fermented beverage from banana juice; no starter culture is added and rudimentary utensils are used during its traditional preparation. The fermentation process to produce banana beer is by the age-long method of chance inoculation and uncontrolled fermentation process. Some of these microorganisms were probably derived from banana juice, water, handlers, containers and some from the roasted sorghum flour. Therefore, the usual variations in the quality and stability of the urwagwa are not unexpected.

The changes in sugar level during the fermentation process are shown in Figure 1. The initial sugar level in banana juice was $19^{\circ} \mathrm{Brix}$, but sugar levels decreased with increase in fermentation time to $7^{\circ}$ Brix. Fermentable sugars in banana juice are about $20-23 \%$ [26]. The main sugars in ripened banana fruit are glucose (19-22\% of total sugars), fructose (12-17\% of total sugars), and sucrose (62-68\% of total sugars) [27]. Sugar content of fully mature ripened banana is quite high and that makes it an ideal substrate for beer making. The initial sugar level plays a significant role in the final alcohol content of the product of fermentation [11]. The initial sugar levels can be improved by improving the degree of ripening the bananas and improving the juice extraction methods. The sugar level decreased with fermentation time probably due to mainly microbes that acted upon the sugars to produce lactic acid and alcohol while they are deriving energy from the sugars in the banana juice and sorghum mixture. The completion of fermentation was indicated by leveling of the Brix level.

The final alcohol content in banana beer (urwagwa) was 7\% (v/v) (Figure 1). From a previous report [15] the alcohol content in tonto (a banana beverage in Uganda) ranged from 6 to 11\%v/v. Similar findings were obtained by Singh et al. [28] on alcoholic banana beverage production. According to Davies [9], a strong alcoholic beer with 11 to $15 \%$ alcohol (v/v) can be obtained from banana juice. The alcohol content of the final product depends on the production procedure, species of banana used, the yeasts present, and the dilution ratio and, in many cases, the weather, since the fermentation process is done at ambient or room temperature without means to control the fermentation temperature. Generally, there are enough yeasts belonging to the genus Sacharomyces in the environment of fermentable sugars to allow the fermentation to proceed $[6,25]$ Changes in $\mathrm{pH}$ and titratable acidity during fermentation of banana juice to produce banana beer were investigated and are shown in Figures 2 . Total titratable acidity increased from 0.18 to $0.9 \%$ lactic acid after 72 hours of fermentation. This resulted in a decrease in $\mathrm{pH}$ from 4.78 to 4 . The progressive fall in $\mathrm{pH}$ and rise in titratable acidity (Figure 2) that occurred during fermentation is characteristic of fermenting cereal grains [28]. For example, [29] reported changes in $\mathrm{pH}$ from 6.10 to 3.98 and titratable acidity from 0.13 to 0.67 during fermentation of mangisi, a traditional cereal beverage in Zimbabwe. The increase in acidity could possibly be due to the activities of lactic acid bacteria breaking down sugars to produce lactic acid among other secondary products, resulting in the sweet-sour taste which makes banana beer popular among the Rwandan people. The microbiological and biochemical changes reported in this study are characteristic of traditional fermentation based on cereals

\begin{tabular}{|l|l|l|l|}
\hline Time $(\mathrm{h})$ & $\begin{array}{l}\text { Total aerobic mesophilic } \\
\text { bacteria }\end{array}$ & Total lactic acid bacteria & Yeast and moulds \\
\hline 0 & $2.82 \times 10^{5}$ & $3.50 \times 10^{5}$ & $1.15 \times 10^{4}$ \\
\hline 12 & $6.21 \times 10^{6}$ & $1.62 \times 10^{7}$ & $3.38 \times 10^{4}$ \\
\hline 24 & $3.2 \times 10^{8}$ & $7.08 \times 10^{8}$ & $9.80 \times 10^{5}$ \\
\hline 36 & $4.4 \times 10^{9}$ & $2.98 \times 10^{9}$ & $2.44 \times 10^{6}$ \\
\hline 48 & $7.62 \times 10^{10}$ & $9.03 \times 10^{11}$ & $1.10 \times 10^{7}$ \\
\hline 62 & $3.55 \times 10^{11}$ & $3.55 \times 10^{12}$ & $2.55 \times 10^{8}$ \\
\hline 72 & $4.12 \times 10^{12}$ & $4.12 \times 10^{13}$ & $3.12 \times 10^{9}$ \\
\hline
\end{tabular}

Table 1: Change in microbial populations during fermentation of banana beer.

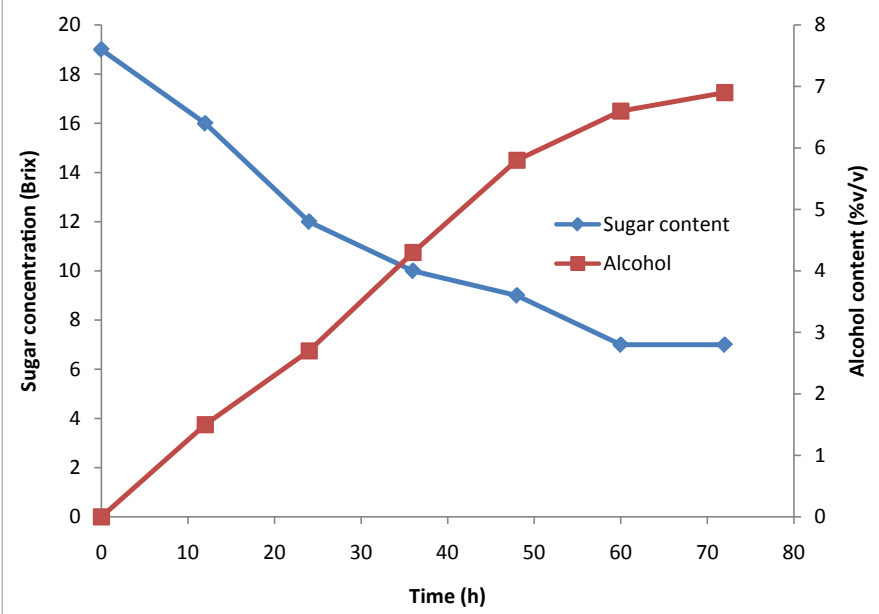

Figure 1: Changes in sugar concentration and alcohol content during fermentation of banana beer. 


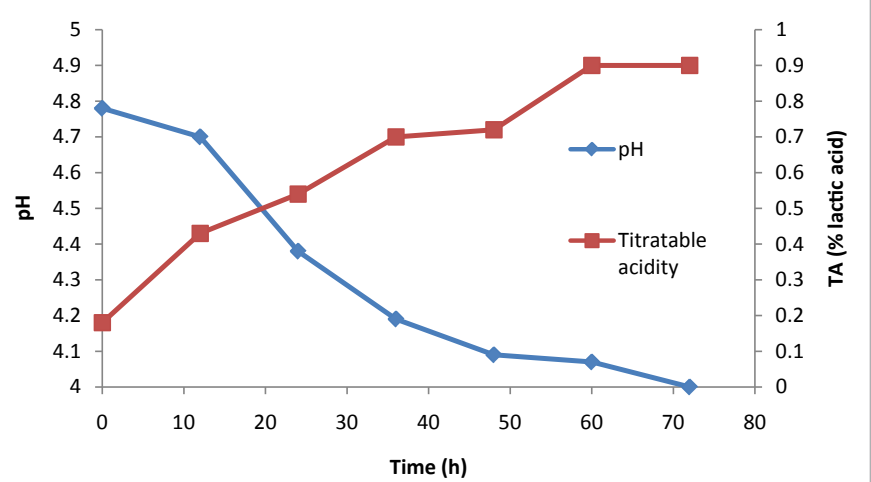

Figure 2: Changes in $\mathrm{pH}$ and titratable acidity during fermentation of banana beer.

and fruits $[7,4,15,30,31]$. The presence of unspecified microorganisms complicates the control of fermentation process and gives products of variable quality. There is need to isolate, identify and characterize the microorganisms involved in the production of urwagwa in attempts to upgrade the traditional beer. Currently, the manufacture of this beer is declining because of poor hygienic quality, short-life, poor yield of ethanol and variations in organoleptic and hygienic quality.

\section{Conclusion}

The microbiological and biochemical changes during a traditional preparation of banana beer, urwagwa, in Rwanda were investigated in this study. The presence of high numbers of yeast and lactic acid bacteria shows that the natural fermentation process is a mixed alcohol and lactic acid fermentation. The results reported could serve as a starting point to understand the microbiological and biochemical processes in urwagwa production with the aim of improving the efficiency of the process. Traditional fermented banana beer is produced at the household level in Rwanda and the microbial and biochemical changes have not been investigated before.

\section{Acknowledgements}

The authors would like to acknowledge the financial assistance from Student Financing Agency for Rwanda (SFAR). We also acknowledge the assistance of Mrs. Mukankwaya Bernadette (Nyirabyenga Ukwe), from Kigali for her knowledge on the art of urwagwa preparation and to allow us to use her facilities at her home to make the urwagwa beer.

\section{References}

1. Mugochi T, Parawira W, Mpofu A, Simango C, Zvauya R (1999). Survival of some species of Salmonella and Shigella in mukumbi, a traditional Zimbabwean wine. Int J Food Sci Nutr 50: 451-455.

2. Campbell-Platt G (1994) Fermented foods: a world perspective. Food Resear Int 27: 253-257.

3. Steinkraus KH, Cullen RE, Pederson CS, Nellis LF, Gavitt BK (1983) Handbook of indigenous fermented foods. New York: Marcel Dekker.

4. Kingamko R, Sjogren E, Svanberg U, Kaijser B (1994) pH and acidity in lacticfermenting cereal gruels: effects on viability of entropathogenic microorganisms. World J Microbiol Biotech 10: 664-669.

5. Lorri W, Svanberg U (1994) Lower prevalence of diarrhea in young children fed lactic acid-fermented cereal gruels. Food Nutr Bull 15: 57- 63.

6. Steinkraus KH (1994) Nutritional significance of fermented foods. Food Resear Int 27: 259-267.

7. Hounhouigan DJ, Nout MJR, Nago CM, Houben JH, Rombouts FM (1994) Microbiological changes in Mawe' during natural fermentation. World $\mathrm{J}$ Microbial Biotech 10: 410-413.
8. Lyumugabe F, Kamaliza G, Bajyana E, Thonart PH (2010) Microbiological and physico-chemical characteristics of Rwandese traditional beer "Ikigage". Afr J Biotechnol 9: 4241-4246.

9. Davies G (1993) Domestic banana-beer production in Mpigi district, Uganda. Infomusa 2: 12-25.

10. FAO (2009) Production data for banana and plantains: 2007-2008.

11. Mohapatra D, Mishra S, Singh CB (2010) Banana and its by-product utilization: an overview. J Sci Ind Res 69: 323-329.

12. Mpyisi JB, Nyarwaya F, Shingiro E (2000) Statistiques agricoles: Production Agricole, Elevage, superficies et utilisation des terres. Annee agricole 2000.

13. Okech SHO, Gaidashova SV, Gold CS, Nyagahungu I, Musumbu JT (2005) The influence of socio-economic and marketing factors on banana production in Rwanda: Results of a participatory rural appraisal. Int J Sustainable Develop World Ecol 12: 149-160.

14. Gaidashova SV, Okech SHO, Gold CS, Nyagahungu I (2005) A quoi tient la préférence pour la banana a bière ? L'example au Rwanda. Info Musa 14: 2-6.

15. Mwesigye PK, Okurut TO (1995) A survey of the production and consumption of traditional of alcoholic beverages in Uganda. Process Biochem 30: 497-501.

16. Okafor N (1992) Commercialization of fermented foods in Sub Saharan Africa. In: Applications of biotechnology to traditional fermented foods. National Academy Press, Washington, DC

17. Aloys N, Angeline N (2009) Traditional fermented foods and beverages in Burundi. Food Resear Int 42: 588-594.

18. Hatungimana $\mathrm{H}$ (2004) Contribution to the study of the microbiological quality of banana wine sold in Bujumbura Town: Case of areas Nyakabiga, Bwiza and Cibitoke. Memory University of Burundi.

19. Sanni Al (1993) The need for process optimization of Africa fermented foods and beverages. Int J Food Microbiol 18: 18-95.

20. Kutyauripo J, Parawira W, Tinofa S, Kudita I, Ndengu C (2009) Investigation of shelf-life extension of sorghum beer (Chibuku) by removing the second conversion of malt. Int J Food Microbiol 129: 271-276.

21. Azodanlou R, Darbelly C, Luisier JL, Villettaz JC, Amado R (2004) Changes in flavor and texture during the ripening of strawberries. Eur Food Res Technol 218: 167-172.

22. Ball DW (2006) Concentration scales for sugar solutions. J Chem Educ 83 1489-1491.

23. Holzapfel W (2002) Appropriate starter culture technologies for small-scale fermentation in developing countries. Int J Food Microbiol 75: 197-212.

24. Jerspersen L (2003) Occurrence and taxonomic characteristics of strains of Saccharomyces cerevisiae predominant in African indigenous fermented foods and beverages. FEMS Yeast Resear 3: 191-200.

25. Nout MJR (1991) Ecology of accelerated natural lactic fermentation of sorghum based infant food formulas. Int J Food Microbiol 12: 217-224.

26. Poland GL, Manion JY, Brenner MW, Harris PL (1983) Sugar changes in the banana during ripening. Irld Eng Chern 30: 340-342.

27. Hammond JB, Egg R, Diggins D, Coble CG (1996) Alcohol from bananas Bioresor Technol 56: 125-130.

28. Singh S, Kulkarni SD, Singh KK (2003) Handling banana chain-Management aspects for an Agri Industrial Approach. 6th All India Congress, National Academy of Agricultural Sciences, Bhopal.

29. Achi OK (1990) Microbiology of obiolor, a Nigerian fermented nonalcoholic beverage. J Appl Bacterial 69: 321-325.

30. Zvauya R, Mugochi T, Parawira W (1997) Microbial and biochemical changes occurring during production of masvusvu and mangisi, traditional Zimbabwean beverages. Plant Foods for Human Nutri 51:43-51.

31. Efiuvwevwere BJO, Akona O (1995) The microbiology of Kununzaki, a cerea beverage from Northern Nigeria, during the fermentation (production) process. World J Microbial Biotech 11: 491-493.

32. Blandino A, Al-Asseri ME, Pandiella SS, Cantero D, Webb C (2003) Cerea based fermented foods and beverages. Food Resear Inte 36: 527-543. 